\title{
Pengaruh Manajemen Laba Pada Nilai Perusahaan Dengan Agresivitas Pajak Sebagai Variabel Intervening
}

\author{
Ni Wayan Intan Saskara Wahyuni ${ }^{1}$ \\ Fakultas Ekonomi dan Bisnis \\ Universitas Udayana, Indonesia. \\ Email: intansaskara42@gmail.com
}

\author{
I Gusti Ayu Nyoman Budiasih ${ }^{2}$ \\ Fakultas Ekonomi dan Bisnis \\ Universitas Udayana, Indonesia.
}

\begin{abstract}
ABSTRAK
Penelitian bertujuan untuk menganalisis dan mengetahui pengaruh manajemen laba pada nilai perusahaan dengan agresivitas pajak sebagai variabel intervening. Implikasi penelitian ini dari segi teoritis untuk dapat mendukung penerapan teori keagenan dan teori sinyal dengan melakukan penelitian secara nyata. Studi dilakukan pada perusahaan sektor pertambangan yang terdaftar di Bursa Efek Indonesia pada tahun 2012-2018. Penelitian ini menggunakan jenis data kuantitatif dan sumber data sekunder dengan jumlah pengamatan yang diperoleh sebanyak 60 pengamatan yang ditentukan menggunakan metode nonprobability sampling dengan teknik purposive sampling sebagai metode pemilihan sampel. Teknik analisis data yang digunakan dalam penelitian ini yakni path analysis dengan program SPSS. Berdasarkan hasil path analysis dalam penelitian ini menunjukkan bahwa manajemen laba tidak berpengaruh pada agresivitas pajak. Agresivitas pajak berpengaruh negatif pada nilai perusahaan. Manajemen laba berpengaruh negatif pada nilai perusahaan. Manajemen laba tidak berpengaruh secara tidak langsung pada nilai perusahaan melalui agresivitas pajak.
\end{abstract}

Kata Kunci : Manajemen Laba; Agresivitas Pajak; Nilai Perusahaan.

\section{The Effect of Earnings Management on Company Value with Tax Aggressiveness As An Intervening Variable}

\footnotetext{
ABSTRACT

This study aims to analyze and determine the effect of earnings management on company value with tax aggressiveness as an intervening variable. The theoretical implications of this research to be able to support the application of agency theory and signaling theory by conducting research on a straightforward basis. The study was conducted on mining companies listed on the Indonesia Stock Exchange in 2012-2018. This study uses quantitative data types and secondary data sources with the number of observations obtained as many as 60 observations determined using the nonprobability sampling method with a purposive sampling technique as a sample selection method. Data analysis technique used in this research is path analysis with SPSS program. Based on the results of the path analysis in this study shows that earnings management has no effect on tax aggressiveness. Tax aggressiveness has a negative effect on company value. Earnings management has a negative effect on company value. Earnings management does not affect indirectly the value of the company through tax aggressiveness.
}

Keywords: $\quad$ Earnings Management; Tax Aggressiveness; Company Value.

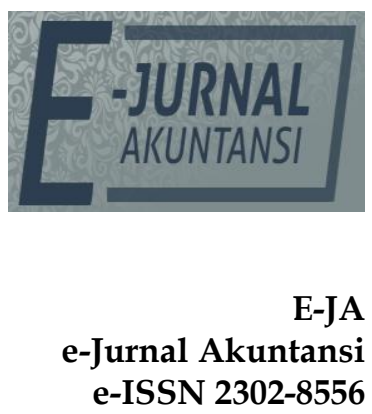

Vol. 29 No. 3

Denpasar, Desember

2019

Hal. 1055-1070

Artikel masuk:

22 Oktober 2019

Tanggal diterima:

4 Desember 2019 


\section{PENDAHULUAN}

Perusahaan yang baik harus mampu mengontrol potensi finansial maupun potensi non-finansial dalam memaksimalkan nilai perusahaan untuk eksistensi perusahaan dalam jangka panjang. Memaksimalkan nilai perusahaan sangat penting artinya bagi suatu perusahaan, karena dengan memaksimalkan nilai perusahaan berarti juga memaksimalkan kemakmuran pemegang saham yang merupakan tujuan utama dari suatu perusahaan. Oleh karenanya, nilai perusahaan merupakan suatu gambaran dari rasa percaya masyarakat kepada perusahaan tersebut dimana nilai perusahaan yang tinggi akan memberikan sinyal baik sehingga dapat menarik minat dari investor untuk menanamkan modalnya di perusahaan tersebut. Selain motivasi untuk memperoleh laba atau keuntungan yang tinggi perusahaan juga memiliki motivasi untuk memiliki nilai perusahaan yang tinggi.

Harga saham biasanya menjadi suatu cerminan dari nilai perusahaan, ketika harga saham dari perusahaan tersebut tinggi, maka semakin tinggi pula nilai dari perusahaan tersebut. Investor sebagai pihak yang menanamkan modal diperusahaan memiliki cara untuk menilai perusahaan terkait keputusan berinvestasi adalah melalui nilai perusahaan yang tercermin dari harga salam perusahaan. Harga saham tidak selamanya tinggi, saham selalu berfluktuatif, dan fluktuasi harga saham perusahaan selalu terjadi pada perusahaanperusahaan yang terdaftar di Bursa Efek Indonesia (BEI) .

Salah satu fenomena fulktuasi harga saham yang menarik untuk dibahas adalah fluktuasi yang terjadi pada harga saham di sektor perusahaan pertambangan seperti yang dikutip dari N. D. Putri (2019) pada tahun 2017, sektor dari perusahaan pertambangan menjadi salah satu sektor yang mengalami underperform. Sektor pertambangan sepanjang perdagangan bursa saham pada tahun 2017, hanya mampu mencatatkan kenaikan sebesar 15,3\%. Kenaikan tersebut dapat dikatakan rendah apabila dibandingkan dengan sektor-sektor perusahaan lainnya yang terdaftar di BEI. Fenomena tersebut mencerminkan terjadinya fluktuasi harga saham diperusahaan pertambangan. Fluktuasi nilai perusahaan menjelaskan bahwa perusahaan akan selalu berusaha untuk memaksimalkan nilai perusahaannya. Salah satu cara untuk memaksimalkan nilai perusahaan tersebut adalah dengan menciptakan keselarasan dan kesinambungan tujuan maupun kepentingan antara manajer dan para pemegang saham (prinsipal). Namun, pada kenyataannya proses maksimalisasi nilai perusahaan seringkali terganggu oleh adanya konflik antara manajer dengan pemegang saham. Konflik diantara kedua belah pihak tersebut sering disebut dengan konflik keagenan.

Konflik keagenan muncul disebabkan oleh adanya asimetri informasi, asimetri informasi tersebut membuat manajer dapat leluasa untuk melakukan manajemen laba, dengan adanya berbagai bentuk praktik manajemen laba perusahaan akan memilih salah satu dari berbagai bentuk manajemen laba disesuaikan dengan tujuan dan motivasi tertentu (Sabatini \& Sudana, 2019). Manajer ketika melakukan praktik manajemen laba salah satu caranya dapat melakukannya dengan cara menurunkan laba (income decreasing) yang dilaporkan untuk memperoleh keuntungan tertentu. Salah satu motivasi 
perusahaan melakukan manajemen laba adalah motivasi perpajakan. Perusahaan akan berusaha meminimalkan beban perusahaannya agar dapat memaksimalkan laba dan meningkatkan nilai perusahaan tersebut. Salah satu beban yang memberatkan perusahaan dan dapat memengaruhi nilai perusahaan adalah beban pajak perusahaan. Tindakan perusahaan untuk meminimalkan beban pajaknya ini disebut dengan agresivitas pajak.

Pada umumnya kasus agresivitas pajak yang berbentuk penghindaran pajak telah banyak terjadi di Indonesia. Dari berbagai sektor perusahaan di Indonesia, salah satu sektor yang sangat berpotensi dan kerap melakukan tindakan penghindaran pajak tersebut adalah sektor pertambangan. Dikutip dari website Asosiasi Pertambangan Indonesia dalam sebuah artikel yang ditulis oleh Dwiarto (2014), tahun 2009 telah ditemukan kasus penghindaran pajak yang dilakukan oleh Bakrie Group. Perusahaan pertambangan besar yang termasuk ke dalam Bakrie Group seperti Kaltim Prima Coal (KPC), Arutmin, dan bahkan Bumi Resources yang merupakan salah satu perusahaan yang listing di Bursa Efek Indonesia terindikasi melakukan praktik penghindaran pajak dengan jumlah 2,176 Triliun Rupiah, dengan rincian KPC sebagai penghindar pajak terbesar yaitu 1,5 Triliun Rupiah, kemudian diikuti oleh BUMI dengan total 376 Miliyar Rupiah, dan yang terakhir yaitu Arutmin senilai 300 Miliyar Rupiah. Fakta tersebut menyiratkan sebuah fenomena bahwa pajak adalah sebuah beban besar bagi perusahaan dalam mencapai laba yang lebih tinggi sehingga perusahaan akan cenderung melakukan penghindaran pajak untuk mengurangi beban pajaknya. Tindakan agresif perusahaan tersebut akan berpengaruh pada nilai perusahaan terutama harga sahamnya di pasar apabila publik sampai mendengar berita agresivitas pajak yang dilakukan oleh sebuah perusahaan.

Penelitian terdahulu terkait manajemen laba dan agresivitas pajak yang dilakukan oleh Kamila \& Martani (2014), Kapoutsou, Tzovas, \& Chalevas (2015), Amidu \& Yorke (2017) menunjukkan hasil penelitian bahwa manajemen laba berpengaruh positif dan signifikan pada agresivitas pajak perusahaan. Sementara itu, hasil yang berbeda ditunjukan pada penelitian yang dilakukan Putri (2014) dan Amril, Puspa, \& Fauziati (2015) yang menunjukan bahwa manajemen laba tidak berpengaruh pada agresivitas pajak perusahaan.

Kemudian pada penelitian terkait manajemen laba dan nilai perusahaan yang dilakukan Susanto \& Christiawan (2016) dan Kamran, Zhao, Ali, \& Sabir (2018) menyatakan bahwa manajemen laba memiliki pengaruh yang positif pada nilai perusahaan. Sebaliknya, Lesmana \& Sukartha (2017), Wijaya, Tantra, \& Budiasih (2018), serta Sabatini \& Sudana (2019), menemukan hasil bahwa manajemen laba berpengaruh negatif pada nilai perusahaan. Sedangkan penelitian yang dilakukan oleh Mukhtaruddin, Relasari, Soebyakto, Irham, \& Abukosim (2014) menemukan hasil bahwa manajemen laba tidak memiliki pengaruh pada nilai perusahaan.

Penelitian terdahulu terkait agresivitas pajak dan nilai perusahaan telah dilakukan oleh Dewanata \& Achmad (2017) dan Dewi \& Dewi (2017) menyatakan bahwa agresivitas pajak berpengaruh positif pada nilai perusahaan. Sebaliknya, penelitian Pradnyana \& Noviari (2017), dan Kusumayani \& Suardana (2017), menyatakan bahwa agresivitas pajak berpengaruh negatif pada nilai 
perusahaan. Sedangkan Desi \& Dharmapala (2005) menyatakan agresivitas pajak tidak berpengaruh pada nilai perusahaan.

Berdasarkan fenomena yang telah diungkapkan dan juga hasil penelitian terdahulu yang menunjukkan sebuah inkonsistensi, maka menarik untuk melakukan penelitian dengan menggunakan ketiga variabel tersebut yaitu manajemen laba, agresivitas pajak, dan nilai perusahaan. Diduga adanya bahwa jika manajemen laba dengan income decreasing yang dilakukan perusahaan akan memengaruhi agresifnya perusahaan tersebut terhadap pajak sehingga kemudian akan berpengaruh pada nilai perusahaan tersebut. Penelitian ini dilakukan pada perusahaan pertambangan yang terdaftar di Bursa Efek Indonesia (BEI) tahun 2012-2018.

Tujuan dari penelitian ini untuk membuktikan secara empiris dan menjelaskan pengaruh manajemen laba pada agresivitas pajak, pengaruh agresivitas pajak pada nilai perusahaan, pengaruh manajemen laba pada nilai perusahaan dan mengetahui serta menganalisa pengaruh tidak langsung manajemen laba melalui agresivitas pajak pada nilai perusahaan.

Manfaat teoritis penelitian ini dapat memberikan pengembangan pengetahuan dalam bidang ilmu akuntansi yang terkait dengan pengaruh manajemen laba pada nilai perusahaan dengan agresivitas pajak sebagai variabel intervening yang dapat mendukung teori keagenan dan teori sinyal. Manfaat praktis bagi perusahaan penelitian ini dapat memberikan referensi tambahan bagi perusahaan mengenai pencapaian nilai perusahaan yang maksimal dengan mengurangi tindakan opportunistik dalam tindakan manajemen laba dan agresivitas pajak. Bagi pengguna utama laporan keuangan penelitian ini dapat memberikan informasi bagi para pengguna utama laporan keuangan (investor dan kreditur) sebagai bahan pertimbangan dalam melakukan investasi dan pemberian kredit. Bagi pemerintah penelitian ini dapat digunakan sebagai bahan pertimbangan dalam meninjau kepatuhan wajib pajak perusahaan pertambangan sehingga penerimaan negara melalui pajak dapat lebih ditingkatkan.

Teori keagenan merupakan teori yang menggambarkan hubungan yang terjadi antara pihak agen dan prinsipal. Pihak yang dimaksud sebagai agen adalah manajemen perusahaan sedangkan pihak yang dimaksud sebagai prinsipal adalah pemegang saham (Jensen \& Meckling, 1976). Teori keagenan pada penelitian ini dapat digunakan untuk memahami perilaku manajemen laba dan agresivitas pajak. Perilaku manajemen laba dan agresivitas pajak dapat terjadi karena adanya asimetri informasi antara pihak agen dan prinsipal, dimana pihak agen memiliki lebih banyak informasi dibandingkan dengan pihak prinsipal. Hal tersebut akan menimbulkan konflik kepentingan diantara kedua pihak sehingga pada umumnya perhatian stakeholder akan cenderung lebih besar dalam mengawasi perusahaan sehingga konflik kepentingan dapat diminimalisir dan pada akhirnya diharapkan akan dapat meningkatkan nilai perusahaan tersebut.

Teori sinyal memusatkan perhatiannya pada pengaruh informasi terhadap perubahan perilaku pemakai informasi tersebut.Teori sinyal pada penelitian ini dapat digunakan untuk memahami bagaimana manajemen laba yang dilakukan oleh manajer akan berdampak pada respon pasar sehingga akan 
memengaruhi nilai perusahaan tersebut. Hal tersebut dikarenakan manajemen laba yang dilakukan manajer dengan maksud dan tujuan tertentu akan menyebabkan informasi yang dipublikasikan tidak mencerminkan informasi yang sebenarnya sehingga pasar akan memberikan respon terkait hal tersebut. Respon yang diberikan dapat berupa respon positif maupun negatif tergantung dari informasi yang diterima oleh pasar tersebut. Pada akhirnya respon-respon yang diberikan oleh pasar tersebut akan memengaruhi nilai dari suatu perusahaan. Berdasarkan kajian pustaka dan penelitian-penelitian sebelumnya, maka kerangka konseptual dapat disajikan sebagai berikut:

$\mathrm{H}_{3}(-)$

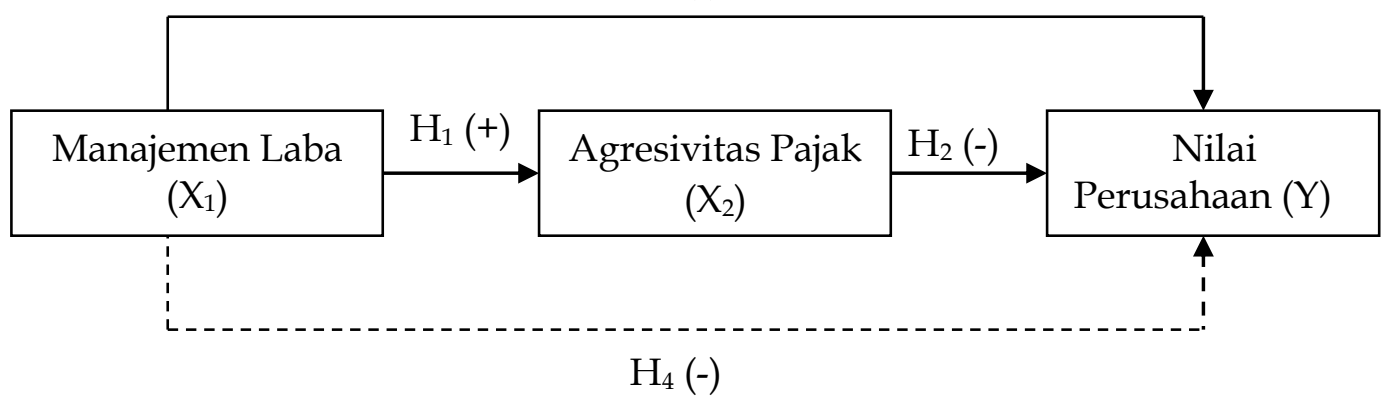

Gambar 1. Kerangka Konseptual

Sumber: Data Penelitian, 2019

Pajak merupakan beban yang harus ditanggung perusahaan sehingga dapat mengurangi keuntungan bersih yang dihasilkan oleh perusahaan tersebut. Maka dari itu, banyak perusahaan cenderung bertujuan untuk mengurangi beban pajak perusahaannya dengan mengurangi jumlah laba yang dilaporkan (income decreasing) untuk menurunkan laba kena pajaknya sehingga perusahaan dapat melakukan penghematan atas beban pajaknya. Pernyataan tersebut sejalan dengan penelitian sebelumnya yang telah dikemukakan oleh Kamila \& Martani (2014) yang menunjukkan hasil penelitian bahwa manajemen laba berpengaruh positif pada agresivitas pajak perusahaan. Hal tersebut juga dikarenakan dasar pengenaan pajak adalah jumlah penghasilan kena pajak. Sehingga dapat disimpulkan bahwa jika pendapatan perusahaan meningkat maka perusahaan akan melakukan income decresing untuk menurunkan pendapatan kena pajak sehingga perusahaan dapat melakukan penghematan atas beban pajak. Berdasarkan uraian tersebut, maka rumusan hipotesis yang diajukan pada penelitian ini adalah:

$\mathrm{H}_{1}$ : Manajemen laba berpengaruh positif pada agresivitas pajak.

Teori keagenan dapat menjelaskan bahwa agresivitas pajak dapat berpengaruh pada nilai perusahaan. Ketika perusahaan menganggap bahwa beban pajak perusahaan merupakan beban yang dapat mengurangi kemampuan ekonomis perusahaan, maka perusahaan tersebut cenderung akan melakukan agresivitas pajak. Hasil penelitian tersebut sejalan denganPenelitian sebelumnya yang telah dikemukakan oleh Hanlon \& Slemrod (2009), Wahab \& Holland (2012), Pradnyana \& Noviari (2017), Kusumayani \& Suardana (2017), serta Devi \& Supadmi (2018) menunjukkan bahwa tindakan agresivitas pajak berpengaruh negatif pada nilai perusahaan. Hasil penelitian tersebut sejalan dengan teori keagenan bahwa asimetri informasi yang terjadi antara manajer dan pemegang 
saham dapat memberikan kesempatan bagi para manajer untuk berperilaku oportunistik yaitu lebih mementingkan kepentingan pribadinya daripada kepentingan pemegang saham perusahaan tersebut. Hal tersebut akan memunculkan kekhawatiran bagi para pemegang saham sehingga dapat menurunkan harga saham perusahaan dan pada akhirnya akan berdampak pada penurunan nilai perusahaan tersebut. Berdasarkan uraian tersebut, maka rumusan hipotesis yang diajukan pada penelitian ini adalah:

$\mathrm{H}_{2}$ : Agresivitas pajak berpengaruh negatif pada nilai perusahaan.

Teori keagenan menjelaskan bahwa ketika manajer melakukan manajemen laba, maka kemakmuran yang akan diterima oleh pemegang saham akan mengalami penurunan (Lesmana \& Sukartha, 2017). Manajemen laba akan menyebabkan informasi yang dipublikasikan tidak mencerminkan informasi yang sebenarnya sehingga akan memberikan sinyal buruk (bad news) kepada pasar terkait hal tersebut. Pasar dalam hal ini investor akan berpikir dua kali untuk melakukan investasi pada perusahaan tersebut sehingga akan menyebabkan harga saham perusahaan cenderung akan menurun dan pada akhirnya akan berdampak pada penurunan nilai perusahaan tersebut.Hasil penelitian tersebut sejalan dengan teori sinyal bahwa manajemen laba yang dilakukan oleh manajer dapat memberikan sinyal buruk (bad news) bagi para investor sehingga menyebabkan harga saham di pasar akan menurun dan hal tersebut mengindikasikan bahwa nilai perusahaan juga mengalami penurunan. Berdasarkan uraian tersebut, maka rumusan hipotesis yang diajukan dalam penelitian ini adalah:

$\mathrm{H}_{3}$ : Manajemen laba berpengaruh negatif pada nilai perusahaan.

Perusahaan yang agresif terhadap pajak cenderung sebelumnya melakukan manajemen laba dengan menurunkan laba yang dilaporkan (income decreasing). Tindakan manajemen laba secara tidak langsung dapat berpengaruh negatif pada nilai perusahaan ketika hal tersebut diketahui oleh publik dan dilakukan melalui agresivitas pajak. Hasil penelitian Suyanto \& Supramono (2012) menunjukkan bahwa semakin agresif perusahaan melakukan manajemen laba, maka dapat dikatakan bahwa tingkat agresivitas pajak perusahaan juga tinggi karena beban pajak semakin kecil dan tindakan agresivitas pajak tersebut akan mengakibatkan turunnya harga saham perusahaan. Turunnya harga saham perusahaan mencerminkan terjadinya penurunan pula pada nilai perusahaan tersebut. Berdasarkan uraian tersebut, maka rumusan hipotesis yang diajukan dalam penelitian ini adalah

$\mathrm{H}_{4}$ : Manajemen laba berpengaruh negatif pada nilai perusahaan secara tidak langsung melalui agresivitas pajak.

\section{METODE PENELITIAN}

Penelitian ini menggunakan pendekatan kuantitaif yang berbentuk asosiatif. Penelitian ini dilakukan di perusahaan pertambangan yang terdaftar di Bursa Efek Indonesia tahun 2012-2018. Sumber data yang digunakan adalah seumber data sekunder dengan menggunakan data laporan keuangan yang diperoleh melalui website resmi BEI yaitu www.idx.co.id dan dari beberapa website perusahaan yang bersangkutan. Objek penelitian adalah agresivitas pajak dan nilai perusahaan. Variabel dependen penelitian ini adalah nilai perusahaan (Y), 
variabel independen manajemen laba $\left(\mathrm{X}_{1}\right)$, dan variabel mediasi (intervening) adalah agresivitas pajak $\left(\mathrm{X}_{2}\right)$. Jenis data yang digunakan data kuantitatif berupa angka-angka yang terdapat dalam laporan keuangan tahunan perusahaan pertambangan di BEI mulai dari tahun 2012-2018.

Nilai perusahaan merupakan pandangan investor terhadap kinerja perusahaan yang tercermin dari harga saham perusahaan tersebut. Nilai perusahaan dapat diukur menggunakan rumus Tobin's $Q$.

Tobin's Q $=(\mathrm{MVE}+\mathrm{DEBT}) / \mathrm{TA}$

Keterangan :

MVE = Market Value of Equity

DEBT $=$ Total kewajiban perusahaan

TA $=$ Total aset perusahaan

Manajemen laba merupakan tindakan yang dilakukan oleh manajer dengan cara menaikkan atau menurunkan laba yang dilaporkan. Perhitungan manajemen laba dengan menggunakan modifted Jones model adalah sebagai berikut. Menghitung total akrual (Herawaty (2008), Febriani \& Asmaranti (2014); dan Susanto \& Christiawan (2016)).

TAit $=$ NIit - CFOit.

Keterangan :

Tait $=$ Total Akrual perusahaan i pada periode $\mathrm{t}$

Niit = LabaBersih perusahaan i pada periode ke $\mathrm{t}$

CFOit = Aliran Kas dari Aktivitas Operasi perusahaan i pada periode ke $\mathrm{t}$

Penentuan koefisien regresi (Dechow, Sloan, \& Sweeney, 1995).

TAit $/$ Ait- $1=\beta_{1}($ l/ Ait- 1$)+\beta_{2}(\Delta$ RECit $/$ Ait- $)-\Delta$ RECit $/$ Ait-1 $)+\beta_{3}($ PPEit $/$ Ait- 1$)+$ cit.

Keterangan :

TAit $\quad=$ Total Akrual Perusahaan i pada periode $\mathrm{t}$

Ait-1 = Total Aset Perusahaan i pada periode $\mathrm{t}-1$

$\triangle$ REVit $\quad=$ Perubahan Pendapatan Perusahaan i pada periode ke $\mathrm{t}$

$\triangle$ RECit $\quad=$ Perubahan Piutang Perusahaan i pada periode ke $\mathrm{t}$

PPEit $\quad=$ Aset Tetap Perusahaan $\mathrm{i}$ pada periode ke $\mathrm{t}$

$\varepsilon \quad=$ error term perusahaan i pada periode ke $\mathrm{t}$

$\beta \quad=$ koefisien regresi

Menghitung Non Discretionary Accruals (NDA) dari koefisien regresi.

NDAit $=\beta_{1}(1 /$ Ait-1 $)+\beta_{2}(\Delta$ RECit $/$ Ait-1 $)-\Delta$ RECit $/$ Ait-1 $)+\beta_{3}($ PPEit $/$ Ait- 1$)$

Keterangan :

NDAit $=$ Non Discretionary Accruals Perusahaan i pada periode $\mathrm{t}$

Ait-1 = Total Aset Perusahaan i pada periode $\mathrm{t}-1$

$\triangle$ REVit $\quad=$ Perubahan Pendapatan Perusahaan i pada periode ke $\mathrm{t}$

$\triangle$ RECit $\quad=$ Perubahan Piutang Perusahaan i pada periode ke $t$

PPEit $\quad=$ Aset Tetap Perusahaan i pada periode ke $\mathrm{t}$

$\beta \quad=$ koefisien regresi

Menghitung Discretionary Accruals (DA)

$\mathrm{DA}_{\mathrm{it}}=($ TAit $/$ Ait-l) - NDAit.

Keterangan :

Dait $=$ Discretionary Accruals Perusahaan i pada periode ke $\mathrm{t}$ 
Tait $\quad=$ Total Akrual Perusahaan i pada periode ke $t$

Ait-1 = Total Aset Perusahaan i pada periode $\mathrm{t}-1$

NDAit $\quad=$ Non Discretionary Accruals Perusahaan $\mathrm{i}$ pada periode ke $\mathrm{t}$

Agresivitas pajak merupakan tindakan wajib pajak yang bertujuan untuk menurunkan laba kena pajak perusahaan melalui perencanaan pajak baik menggunakan cara yang tergolong tax evasion maupun tax avoidance agar beban pajak perusahaan dapat berada pada posisi seminimal mungkin. Penelitian ini menggunakan proksi Generally Accepted Accounting Principles Effective Tax Rate (GAAP ETR). GAAPETR dihitung dengan menggunakan rumus sebagai berikut: GAAP ETR $=$ TE $/$ PI

Keterangan:

GAAP ETR =Generally Accepted Accounting Principles Effective Tax Rate

TE $\quad=$ Tax Expense (Total beban pajak penghasilan)

PI $\quad=$ Pretax Income(Laba sebelum pajak penghasilan)

Teknik analisis data yang digunakan dalam penelitian ini adalah analisis jalur (path analysis), dikarenakan pengujian pengaruh variabel independen pada variabel dependennya menggunakan variabel mediasi (intervening variable). Penyusunan model juga dapat dinyatakan dalam bentuk persamaan diagram jalur yaitu sebagai berikut:

Substruktur 1

$\mathrm{X}_{2}=\mathrm{cX}+\mathrm{e}_{1}$

Substruktur 2

$\mathrm{Y}=\mathrm{aX} \mathrm{X}_{1}+\mathrm{dX}_{2}+\mathrm{e}_{2}$

Keterangan:

$\mathrm{X}_{1} \quad=$ Manajemen Laba

$\mathrm{X}_{2} \quad=$ Agresivitas Pajak

$\mathrm{Y}=$ Nilai Perusahaan

$\mathrm{a}, \mathrm{b}, \mathrm{c}, \mathrm{d}=$ Standardisasi Koefisien Regresi

$\mathrm{Pe} 1, \mathrm{Pe} 2=$ error

\section{HASIL DAN PEMBAHASAN}

Sampel dalam penelitian ini diperoleh melalui teknik purposive sampling dengan jumlah sampel yang digunakan adalah 13 perusahaan pertambangan dari tahun 2012-2018. Perusahaan pertambangan yang menjadi sampel penelitian ini terdiri dari 4 sektor yang berbeda, sektor I yaitu Sub-Sektor Batubara terdiri dari 8 perusahaan, sektor II yaitu Sub-Sektor Minyak Gas dan Bumi terdiri dari 3 perusahaan, sektor III yaitu Sub-Sektor Logam dan Mineral terdiri dari 1 perusahaan, dan sektor IV yaitu Sub-Sektor Batu-batuan terdiri dari 1 perusahaan. Jumlah sampel yang diperoleh dalam penelitian ini adalah sebanyak 13 perusahaan pertambangan dengan total pengamatan dari tahun 2012-2018 sebanyak 91 pengamatan. Namun pada penelitian ini, manajemen laba yang digunakan adalah manajemen laba dengan income decreasing sehingga manajemen laba dengan income increasing dikeluarkan dari pengamatan. Setelah melakukan perhitungan discretionary accruals, didapatkan sebanyak 31 pengamatan yang memiliki discretionary accruals positif yang menandakan manajemen laba dilakukan dengan income increasing sehingga total pengamatan 
berkurang menjadi 60 pengamatan. Hasil uji statistik deskriptif dalam penelitian ini dapat dilihat pada Tabel 1.

Tabel 1. Statistik Deskriptif Variabel Penelitian

\begin{tabular}{lrrrr}
\hline & Manajemen Laba & \multicolumn{2}{r}{ Agresivitas Pajak } & \multicolumn{2}{c}{ Nilai Perusahaan } \\
\hline $\mathrm{N}$ & \multicolumn{1}{c}{ Valid } & 60 & 60 & 60 \\
& Missing & 0 & 0 & 0 \\
Mean & 0,0978150 & 0,3544350 & 1,3077200 \\
Std. Error of Mean & 0,01057131 & 0,01911711 & 0,10388481 \\
& & & 1,0247 \\
Median & 0,0792 & 0,3083 & $0,2472^{\mathrm{a}}$ \\
Mode & $0,0036^{\mathrm{a}}$ & $0,1372^{\mathrm{a}}$ & 0,80468829 \\
Std. Deviation & 0,08188505 & 0,14808053 & 0,648 \\
& & & 4,08100 \\
Variance & 0,007 & 0,022 & 0,24720 \\
Range & 0,34950 & 0,99650 & 4,32820 \\
Minimum & 0,00360 & 0,13720 & 78,46320 \\
Maximum & 0,35310 & 1,13370 & 21,26610 & \\
Sum & 5,86890 & &
\end{tabular}

Sumber: Data Penelitian, 2019

Berdasarkan hasil pengujian statistik deskriptif pada Tabel 1, dapat dijelaskan statistik deskriptif dari masing-masing variabel penelitian. Variabel manajemen laba (Discretionary Accruals) memiliki nilai maksimum sebesar 0,35310, nilai minimum 0,00360. Nilai rata-rata (mean) sebesar 0,0978 dengan standar deviasi sebesar 0,0818 menunjukkan bahwa perusahaan pertambangan yang menjadi sampel penelitian rata-rata melakukan manajemen laba khususnya dengan income decreasing sebesar 9,78\%. Variabel agresivitas pajak (GAAP ETR) menunjukan seberapa besar upaya perusahaan menurunkan beban pajak dengan cara menurunkan laba. Nilai maksimun agresivitas pajak sebesar 1,3370, nilai minimum 0,13720 dan nilai rata-rata (mean) sebesar 0,3544 dengan standar deviasi sebesar 0,1480 menunjukkan bahwa perusahaan pertambangan yang menjadi sampel penelitian rata-rata melakukan upaya penurunan pajak dengan cara menurunkan laba sehingga terkena koreksi fiskal cukup besar yang menyebabkan persentase beban pajak terutangnya sebesar $35,44 \%$ dari laba sebelum pajak. Variabel nilai perusahaan (Tobin's Q) memiliki nilai maksimum 4,32820 dan nilai minimum 0,24720 serta Nilai rata-rata (mean) adalah sebesar 1,3077 dengan standar deviasi sebesar 0,8046 berarti bahwa perusahaan pertambangan yang menjadi sampel penelitian rata-rata memiliki nilai perusahaan sebesar 1,3077. Nilai rata-rata ini berada di atas 1 yang berarti bahwa harga saham perusahaan di pasar lebih tinggi dari harga wajar saham tersebut (overvalued). Hal tersebut mengindikasikan bahwa pasar rata-rata tertarik untuk berinvestasi pada perusahaan pertambangan.

Uji asumsi klasik dilakukan untuk meyakinkan bahwa model regresi yang dibuat telah valid sehingga model layak diteliti dan dapat dianalisis dengan baik. Hasil dari uji asumsi klasik meliputi uji normalitas, uji autokorelasi, uji multikolinieritas dan uji heterokedastisitas. Hasil uji normalitas menunjukkan bahwa data pada model regresi Asymp.Sig (2-tailed) substruktur 1 sebesar 
0,199dan substruktur 2 sebesar 0,318 yang berada di atas tingkat signifikansi yang telah ditentukan yaitu 0,05 maka, penelitian berdistribusi normal. Hasil uji autokorelasi menunjukkan bahwa karena nilai d-statistik berada di antara du dan $4-\mathrm{d}_{\mathrm{u}}(1,6162<1,678<2,3838)$ atau berada pada daerah tidak terdapat autokorelasi, maka model regresi substruktur 1 tidak mengandung gejala autokorelasi dan nilai d-statistik berada pada nilai $\mathrm{d}_{W}<\mathrm{d}_{\mathrm{L}}(1,226<1,5144)$ atau berada pada daerah terjadi autokorelasi positif, maka model regresi substruktur 2 mengandung gejala autokorelasi positif. Hasil uji multikolinieritas regresi substruktur 1 tidak memerlukan uji multikolinearitas karena regresi ini hanya terdiri dari satu variabel independen dan untuk regresi substruktur 2 koefisien tolerance lebih kecil dari 10 persen dan VIF lebih besar dari 10, hal ini berarti tidak ada gejala multikolinearitas dari model regresi sehingga model tersebut layak digunakan untuk memprediksi.

Hasil perhitungan koefisien path untuk regresi substruktur 1 dan 2 dapat dilihat pada Tabel 2 dan Tabel 3.

Tabel 2. Hasil Analisis Jalur Regresi Substruktur 1

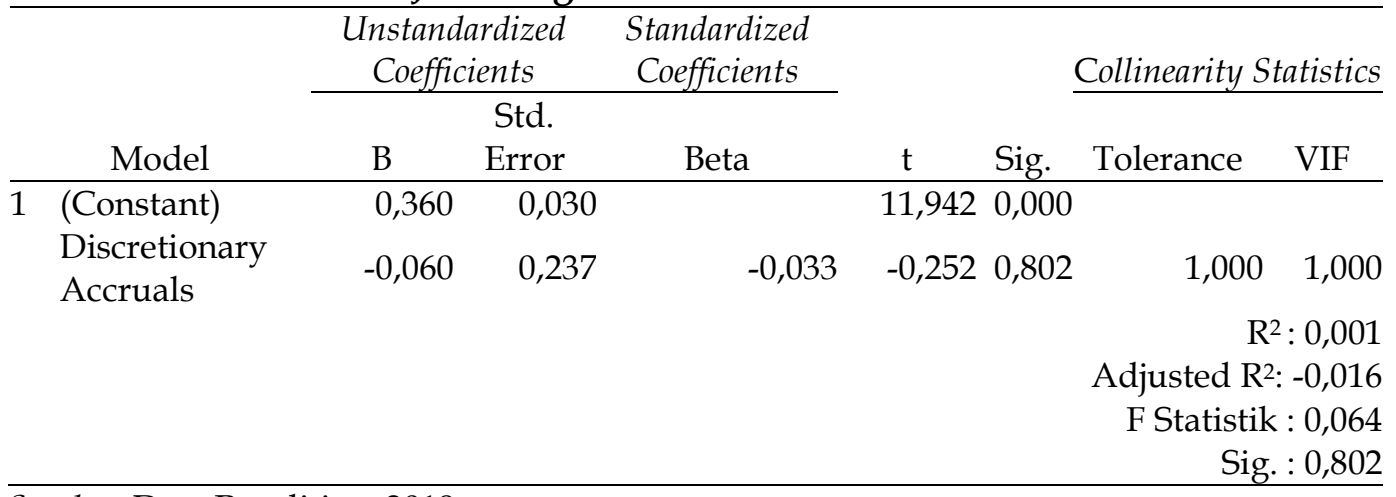

Sumber: Data Penelitian, 2019

Berdasarkan hasil analisis jalur untuk regresi substruktur 1 yang terdapat pada Tabel 2, maka persamaan strukturnya adalah sebagai berikut.

$\mathrm{X}_{2}=\mathrm{cX}_{1}+\mathrm{e}_{1}$

$X_{2}=-0,033 X_{1}+e_{1}$

Tabel 3. Hasil Analisis Jalur Regresi Substruktur 2

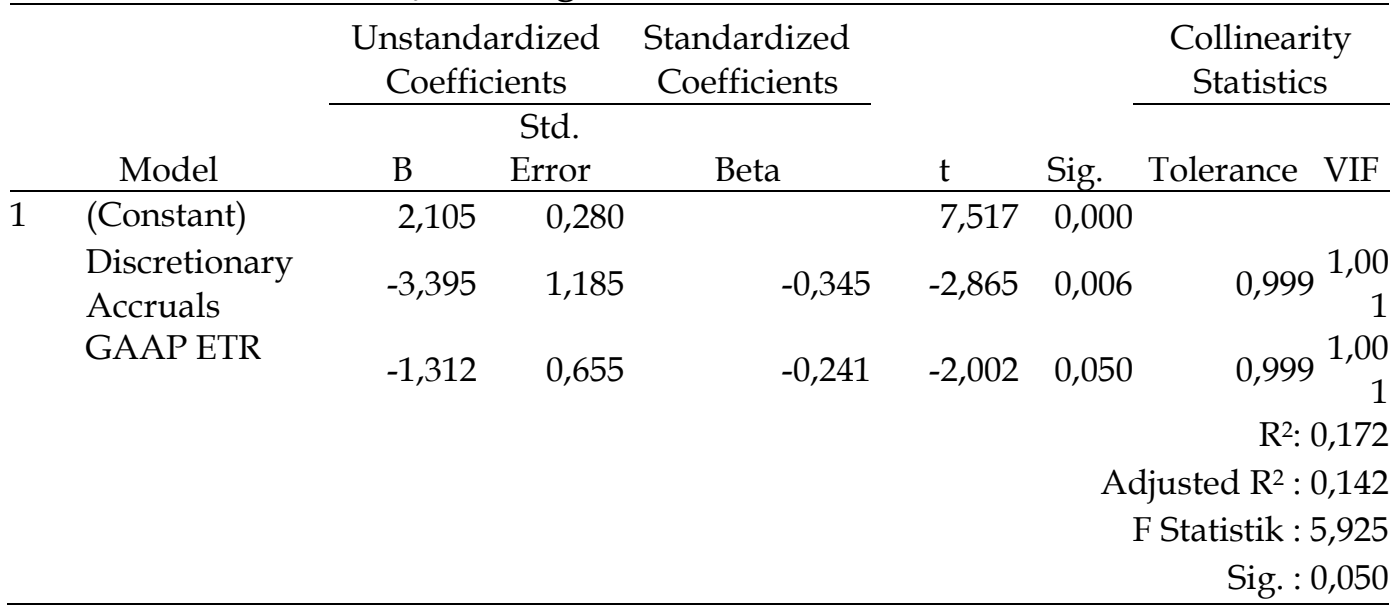

Sumber: Data Penelitian, 2019 
Berdasarkan hasil analisis jalur untuk regresi substruktur 2 yang terdapat pada Tabel 3, maka persamaan strukturalnya adalah sebagai berikut.

$$
\begin{gathered}
Y=a X_{1}+d X_{2}+e_{2} \\
Y=-0,345 X_{1}+-0,241 X_{2}+c_{2}
\end{gathered}
$$

Sementara itu, besarnya nilai koefisien pengaruh manajemen laba pada nilai perusahaan sebelum adanya mediasi (b), yaitu sebesar $-0,337$.

Tabel 4. Nilai Koefisien PengaruhManajemen Laba pada NilaiPerusahaan

\begin{tabular}{|c|c|c|c|c|c|c|c|c|}
\hline & \multirow[b]{2}{*}{ Model } & \multicolumn{2}{|c|}{$\begin{array}{l}\text { Unstandardized } \\
\text { Coefficients }\end{array}$} & \multirow{2}{*}{$\begin{array}{c}\begin{array}{c}\text { Standardized } \\
\text { Coefficients }\end{array} \\
\text { Beta }\end{array}$} & \multirow[b]{2}{*}{$\mathrm{t}$} & \multirow[b]{2}{*}{ Sig. } & \multicolumn{2}{|c|}{$\begin{array}{l}\text { Collinearity } \\
\text { Statistics }\end{array}$} \\
\hline & & B & $\begin{array}{l}\text { Std. } \\
\text { Error }\end{array}$ & & & & Tolerance & VIF \\
\hline \multirow[t]{2}{*}{1} & (Constant) & 1,632 & 0,154 & & 10,569 & 0,000 & & \\
\hline & $\begin{array}{c}\text { Discretionary } \\
\text { Accruals }\end{array}$ & $-3,316$ & 1,215 & $-0,337$ & $-2,730$ & 0,008 & 1,000 & 1,000 \\
\hline
\end{tabular}
Sebelum Adanya Mediasi

Sumber: Data Penelitian, 2019

Pemeriksaan validitas model dalam analisis jalur menggunakan indikator koefisien determinasi total $\left(\mathrm{R}^{2} \mathrm{M}\right)$ dengan terlebih dahulu menghitung nilai standard error dengan perhitungan sebagai berikut.

$P_{\mathrm{ei}}=\sqrt{1-\mathrm{R}^{2}}$

$\mathrm{P}_{\mathrm{e} 1}=\sqrt{1-0,001}=0,9994$

$\mathrm{P}_{\mathrm{e} 2}=\sqrt{1-0,172}=0,9099$

Maka dari itu, nilai koefisien determinasi total $\left(\mathrm{R}^{2} \mathrm{M}\right)$ adalah sebagai berikut.

$\mathrm{R}^{2} \mathrm{M}=1-\left(\mathrm{P}_{\mathrm{e} 1}\right)^{2}\left(\mathrm{P}_{\mathrm{e} 2}\right)^{2}-\left(\mathrm{P}_{\mathrm{ep}}\right)^{2}$

$\mathrm{R}^{2} \mathrm{M}=1-\left(\mathrm{P}_{\mathrm{e} 1}\right)^{2}\left(\mathrm{P}_{\mathrm{e} 2}\right)^{2}$

$\mathrm{R}^{2} \mathrm{M}=1-\left(\left(0,9994^{2}\right)\left(0,9099^{2}\right)\right)$

$\mathrm{R}^{2} \mathrm{M}=0,173$

Koefisien determinasi total sebesar 0,173 mempunyai arti bahwa sebesar 17,3 persen informasi yang terkandung dapat dijelaskan oleh model yang dibentuk, sedangkan sisanya yaitu 82,7 persen dijelaskan oleh variabel lain diluar model yang dibentuk.Perhitungan pengaruh antar variabel diterangkan dalam Tabel 5 sebagai berikut.

Tabel 5. Pengaruh Langsung, Pengaruh Tidak Langsung dan Pengaruh Total Variabel Manajemen Laba(X1), Agresivitas Pajak(X2) dan Nilai Perusahaan(Y)

\begin{tabular}{ccrr}
\hline Pengaruh Variabel & $\begin{array}{c}\text { Pengaruh } \\
\text { Langsung }\end{array}$ & $\begin{array}{c}\text { PengaruhTidak } \\
\text { Langsung }(\mathrm{c} \times \mathrm{d})\end{array}$ & $\begin{array}{c}\text { Pengaruh Total } \\
(\mathrm{a}+(\mathrm{c} \times \mathrm{d}))\end{array}$ \\
\hline $\begin{array}{c}\text { Manajemen Laba pada } \\
\text { Nilai Perusahaan }\end{array}$ & $\mathrm{a}=-0,345$ & 0,083145 & $-0,261855$ \\
$\begin{array}{c}\text { Manajemen Laba pada } \\
\text { Agresivitas Pajak }\end{array}$ & $\mathrm{c}=-0,033$ & & $-0,033$ \\
$\begin{array}{c}\text { Agresivitas Pajak pada } \\
\text { Nilai Perusahaan }\end{array}$ & $\mathrm{d}=-0,241$ & $-0,241$
\end{tabular}

Sumber: Data Penelitian, 2019

Hipotesis pertama menyatakan bahwa manajemen laba berpengaruh positif pada agresivitas pajak. Berdasarkan hasil dari analisis jalur (path analysis), variabel manajemen laba memiliki koefisien regresi standard bernilai -0,033 yang 
memiliki tingkat signifikansi sebesar 0,802 lebih besar dari 0,05. Hal ini berarti manajemen laba tidak berpengaruh pada agresivitas pajak sehingga $\mathrm{H}_{1}$ ditolak. Hal ini berarti bahwa besar kecilnya manajemen laba tidak akan mempengaruhi besar kecilnya agresivitas pajak yang dilakukan oleh pihak manajemen. Hasil penelitian ini sejalan dengan hasil penelitian yang dikemukakan oleh Putri (2014) mengilustrasikan aktivitas manajemen laba dengan objek aktiva tetap. Pada aktivitas manajemen laba dengan objek estimasi umur ekonomis aktiva tetap, perusahaan dapat melakukan manajemen laba dengan cara membuat biaya depresiasi periode berjalan menjadi lebih besar dibandingkan biaya depresiasi periode sebelumnya. Oleh karena itu, perusahaan cenderung akan mengganti umur ekonomis aktiva tetap perusahaan menjadi lebih pendek. Perubahan ini secara langsung akan membuat laba periode berjalan menjadi lebih kecil dibandingkan dengan laba sesungguhnya.

Hipotesis kedua menyatakan bahwa agresivitas pajak berpengaruh negatif pada nilai perusahaan. Berdasarkan hasil dari analisis jalur (path analysis), variabel agresivitas pajak memiliki koefisien regresi standar sebesar -0,241 dengan tingkat signifikansi sebesar 0,050 lebih kecil dari 0,05. Hal ini berarti agresivitas pajak berpengaruh negatif pada nilai perusahaan sehingga $\mathrm{H}_{2}$ diterima, karena semakin tinggi agresivitas pajak yang dilakukan oleh pihak manajemen maka dapat menurunkan nilai perusahaan apabila tindakan tersebut dilakukan dengan niatan negatif seperti mengutamakan kepentingan pribadi dan niatan negatif tersebut diketahui oleh publik (khalayak umum). Hasil penelitian ini sejalan dengan hasil penelitian yang dikemukakan oleh Devi dan Supadmi (2018) yang menyatakan bahwa agresivitas pajak berpengaruh negatif pada nilai perusahaan.

Hipotesis ketiga menyatakan bahwa manajemen laba berpengaruh negatif pada nilai perusahaan. Berdasarkan hasil analisis jalur, variabel manajemen laba memiliki koefisien regresi standar sebesar -0,345 dengan tingkat signifikansi sebesar 0,006 lebih kecil dari 0,05. Hal ini berarti manajemen laba berpengaruh negatif pada nilai perusahaan sehingga $\mathrm{H}_{3}$ diterima, karena semakin tinggi manajemen laba maka dapat menurunkan nilai perusahaan karena manajemen laba tidak dilakukan dengan pelaku opportunistik serta akan menyebabkan informasi laba yang disajikan tidak memberikan informasi laba yang sesungguhnya (mengurangi kualitas laba yang disajikan dalam laporan keuangan). Hasil penelitian ini sejalan dengan hasil penelitian yang dikemukakan oleh Gill, Biger, \& Mand (2013), Tangjitprom. N (2013), Febriani \& Asmaranti (2014), Lesmana \& Sukartha (2017), serta Wijaya et al., (2018) yang menyatakan bahwa manajemen laba berpengaruh negatif pada nilai perusahaan. Tindakan manajemen laba dengan perilaku opportunistik ternyata tidak dilakukan oleh manajemen untuk meningkatkan nilai perusahaan sehingga hal tersebut akan menjadi sinyal-sinyal negatif yang dapat direaksi oleh publik dan pada akhirnya akan berdampak pada menurunnya nilai perusahaan tersebut.

Hipotesis keempat menyatakan bahwa manajemena laba secara tidak langsung berpengaruh negatif pada nilai perusahaan melalui agresivitas pajak. Berdasarkan hasil analisis jalur yang mengacu pada model yang digunakan oleh Solimun (2010) didapatkan hasil perhitungan nilai koefisien a $=-0,345$ dengan sig $t=0,006$, nilai koefisien $b=-0,337$ dengan sig $t=0,008$, nilai koefisien $c=-0,033$ 
dengan sig $\mathrm{t}=0,802$, dan nilai koefisien $\mathrm{d}=-0,241$ dengan $\operatorname{sig} \mathrm{t}=0,050$. Berdasarkan hasil perhitungan tersebut, maka dapat disimpulkan bahwa bahwa koefisen d signifikan, koefisien c tidak signifikan, dan koefisien a (melibatkan variabel mediasi) maupun koefisien $b$ (melibatkan variabel mediasi) sama-sama tidak signifikan. Sehingga dapat disimpulkan bahwa variabel mediasi agresivitas pajak tidak mampu memediasi pengaruh manajemen laba terhadap nilai perusahaan. Karena terdapat pengaruh secara langsung variabel agresivitas pajak terhadap nilai perusahaan, itu artinya bahwa agresivitas pajak perpotensi sebagai variabel bebas, dan bukan sebagai variabel mediasi.Hasil penelitian menyatakan bahwa manajemen laba tidak berpengaruh secara tidak langsung pada nilai perusahaan melalui agresivitas pajak dikarenakan terdapatnya perbedaan antara ketentuan dalam UU Perpajakan dan PSAK terkait pengakuan pendapatan dan beban karena memiliki tujuan yang berbeda. Oleh karena itu, meskipun perusahaan melakukan manajemen laba, tidak akan berdampak pada tujuan meminimalkan pajak, karena terdapat perbedaan ketentuan terkait pengakuan pendapatan dan beban antara laba komersial dan laga fiskal. Hasil penelitian ini tidak sejalan dengan penelitian yang telah dilakukan oleh Suyanto \& Supramono (2012) yang menyatakan bahwa semakin agresif perusahaan melakukan manajemen laba, maka dapat dikatakan bahwa tingkat agresivitas pajak perusahaan juga tinggi karena beban pajak semakin kecil dan tindakan agresivitas pajak tersebut akan mengakibatkan turunnya harga saham perusahaan.

\section{SIMPULAN}

Berdasarkan hasil penelitianmaka dapat disimpulkan bahwa,manajemen laba tidak berpengaruh pada agresivitas pajak perusahaan, hal ini berarti bahwa besar kecilnya manajemen laba tidak akan mempengaruhi besar kecilnya agresivitas pajak yang dilakukan oleh pihak manajemen. Agresivitas pajak berpengaruh negatif pada nilai perusahaan,hal ini berarti bahwa semakin tinggi agresivitas pajak yang dilakukan oleh pihak manajemen maka dapat menurunkan nilai perusahaan apabila tindakan tersebut dilakukan dengan niatan negatif seperti mengutamakan kepentingan pribadi dan niatan negatif tersebut diketahui oleh publik (khalayak umum). Manajemen laba berpengaruh negatif pada nilai perusahaan, hal ini berarti bahwa semakin tinggi manajemen laba maka dapat menurunkan nilai perusahaan karena manajemen laba tidak dilakukan dengan pelaku opportunistik serta akan menyebabkan informasi laba yang disajikan tidak memberikan informasi laba yang sesungguhnya (mengurangi kualitas laba yang disajikan dalam laporan keuangan). Manajemen laba tidak berpengaruh secara tidak langsung pada nilai perusahaan melalui agresivitas pajak, hal ini berarti bahwa manajemen laba tidak dapat mempengaruhi agresivitas pajak yang dilakukan oleh manajemen sehingga tidak dapat mempengaruhi nilai perusahaan tersebut dikarenakan terdapatnya perbedaan antara ketentuan dalam UU Perpajakan dan PSAK tekait pengakuan pendapatan dan beban karena memiliki tujuan yang berbeda.

Saran yang dapat diberikan adalahdalam menilai kelayakan investasi, para investor tidak hanya berpatokan pada informasi laba perusahaan tetapi juga pada informasi fundamental perusahaan seperti analisis rasio-rasio keuangan. 
Perusahaan dapat lebih mencegah tindakan-tindakan opportunistik serta memperbaiki segala kebijakan yang diambil agar tidak melanggar ketentuanketentuan akuntansi dan perpajakan sehingga publik tetap percaya pada perusahaan tersebut serta akan menilai perusahaan tersebut baik. Penelitian ini menyatakan hasil penelitian bahwa agresivitas pajak bukan sebagai variabel mediasi antara pengaruh manajemen laba pada nilai perusahaan. Peneliti selanjutnya dapat meneliti variabel-variabel lainnya yang dapat digunakan sebagai mediasi atau variabel intervening.

\section{REFERENSI}

Amidu, M., \& Yorke, S. . (2017). Tax Avoidance and Earnings Management of Firms in Ghana: Does The Funding Strategy Matter? International Journal of Critical Accounting, 9(3), 239-264.

Amril, A., Puspa, D. ., \& Fauziati, P. (2015). Pengaruh Manajemen Laba dan Corporate Governance terhadap Agresivitas Pajak Perusahan manufaktur yang Listing di Bursa Efek Indonesia (BEI) Periode 2011-2013. Jurnal Akuntansi Universitas Bung Hatta, 7(1).

Dechow, P. M., Sloan, R. ., \& Sweeney, A. . (1995). Detecting Earnings Management. The Accounting Review, 70(2), 193-225.

Desi, M. ., \& Dharmapala, D. (2005). orporate Tax Avoidance and Firm Value. The Review of Economics and Statistics, 91(2009), 537-546.

Devi, P. N. C., \& Supadmi, N. . (2018). Pengaruh Agaresivitas Pajak pada Nilai Perusahaan dengan Ukuran Perusahaan sebagai Pemoderasi. E-Jurnal Akuntansi Universitas Udayana, 22(3), 2257-2283.

Dewanata, P., \& Achmad, T. (2017). Pengaruh Perencanaan Pajak terhadap Nilai Perusahaan dengan Kualitas Corporate Governance sebagai Variabel Moderasi (Studi Empiris pada Perusahaan manufaktur yang Terdaftar di BEI Tahun 2012-2014). Diponegoro Journal of Accounting, 10(2), 211-230.

Dewi, A. ., \& Dewi, L. G. . (2017). Transparansi Informasi Memoderasi Pengaruh Agresivitas Pajak pada Nilai Perusahaan Pertambangan di bursa Efek Indonesia. Akuntabilitas : Jurnal Ilmu Akuntansi, 10(2), 211-230.

Dwiarto, D. (2014). Pajak Perusahaan Tambang. Retrieved July 8, 2019, from http://ww.ima-api.com

Febriani, D., \& Asmaranti, Y. (2014). Pengaruh Manajemen Laba terhadap Nilai Perusahaan dengan Mekanisme Corporate Governance sebagai Variabel Pemoderasi pada Perusahaan yang terdaftar di Bursa Efek Indonesia. Jurnal Akuntansi Dan Keuangan, 19(1), 81-104.

Gill, A., Biger, N., \& Mand, H. . (2013). Earnings Management, Firm Performance, and the Value of Indian Manufacturing Firms. International Research Journal of Finance and Economics, (116), 120-132.

Hanlon, M., \& Slemrod, J. (2009). What does tax aggressiveness signal? Evidence from stock price reactions to news about tax shelter involvement. Journal of Public Economics, 93(1-2), 126-141.

Herawaty, V. (2008). Peran Praktek Corporate Governance sebagai Moderating Variable dari Pengaruh Earnings Management terhadap Nilai Perusahaan. Jurnal Akuntansi Dan Keuangan, 10(2), 97-108.

Jensen, M. ., \& Meckling, W. . (1976). Theory of the Firm : Managerial Behavior, 
Agency Costs and Ownership Structure. Journal of Financial Economics, 3, 305-360.

Kamila, P. ., \& Martani, D. (2014). Analisis Hubungan Agresivitas Pelaporan Pada saat terjadinya Penurunan Tarif Pajak. Simposium Nasional Akuntansi XVII Lombok, 1-19.

Kamran, M. ., Zhao, Z., Ali, H. ., \& Sabir, F. (2018). Does Earning Management Mediate the Impact of Financial Policies on Market Value of Firms? A Comparative Study of China and Pakistan. International Journal of Financial Engineering, 5(1), 1850006.

Kapoutsou, E., Tzovas, C., \& Chalevas, C. (2015). Earning Management and Income Tax Evidence from Greece. Corporate Ownership and Control, 12(2), 511-529.

Kusumayani, H. A., \& Suardana, K. . (2017). Kepemilikan Manajerial dan Kepemilikan Institusional sebagai Pemoderasi Pengaruh Perencanaan Pajak pada Nilai Perusahaan. E-Jurnal Akuntansi Universitas Udayana, 18(1), 646673.

Lesmana, I. P. A. ., \& Sukartha, I. . (2017). Pengaruh Manajemen Laba apada Nilai Perusahaan Manufaktur yang terdaftar di Bursa Efek Indonesia Tahun 20122015. E-Journal Akuntansi Universitas Udayana, 19(2), 1060-1087.

Mukhtaruddin, Y., Relasari, Soebyakto, B. ., Irham, A. ., \& Abukosim. (2014). Earning Management, corporate social responsibility disclosure and firm's value: Empirical study on manufacturing listed on IDX period 2010-2012. Net Journal of Business Management, 2(3), 48-56.

Pradnyana, I. B. G. ., \& Noviari, N. (2017). Pengaruh Perencanaan Pajak terhadap Nilai Perusahaan dengan Transparansi Perusahaan sebagai Variabel Moderasi. E-Jurnal Akuntansi Universitas Udayana, 18(2), 1398-1425.

Putri, L. T. . (2014). Pengaruh Likuiditas, Manajemen Laba dan Corporate Governance terhadap Agresivitas Pajak Perusahaan (Studi Empiris pada Perusahaan yang Terdaftar di BEI Periode 2008-2012). Jurnal Akuntansi Universitas Negeri Padang, 2(1).

Putri, N. D. (2019). Lesu di 2017 Saham Sektor Pertambangan dan Properti Mulai Rebound. Retrieved May 11, 2019, from Kontan website: https://investasi.kontan.co.id/news/lesu-di-2017-saham-sektorpertambangan-dan-properti-mulai-rebound

Sabatini, K., \& Sudana, I. P. (2019). Pengaruh Pengungkapan CSR terhadap Nilai Perusahaan dengan Manajerial Laba sebagai Variabel Moderasi. Jurnal Ilmiah Akuntansi Dan Bisnis, 14(1), 56-69.

Susanto, S., \& Christiawan, Y. . (2016). Pengaruh Earning Management terhadap Firm Value. Business Accounting Review, 4(1), 205-216.

Suyanto, D. ., \& Supramono. (2012). Likuiditas, Leverage, Komisaris Independen dan Manajemen Laba terhadap Agresivitas Pajak Perusahaan. Jurnal Keuangan Dan Perbankan, 16(2), 167-177.

Tangjitprom. N. (2013). The Role of Corporate Governance in Reducing the Negative Effect of Earning Management. International Journal of Economics and Finance, 5(3), 213-220.

Wahab, N. S. ., \& Holland, K. (2012). Tax Planning, Corporate Govermance, and Equity Value. The British Accounting Review, 1-43. 
Wijaya, Tantra, D. C., \& Budiasih, I. G. A. . (2018). Manajemen Laba Terhadap Nilai Perusahaan Pada Pergantian CEO. E-Journal Akuntansi Universitas Udayana, 25(3), 1662-1689. 